\title{
RELATIONSHIPS BETWEEN THE INTERNAL AND EXTERNAL EVOLUTION OF THE MONTE CUCCO KARST COMPLEX. UMBRIA, CENTRAL ITALY.
}

\author{
Fausto Guzzetti
}

\begin{abstract}
SUMMARY
The relationships between the internal and external evolution of the Mt. Cucco karst complex are studied.

A classic set of equations, involving the oxidation of hydrogen sulphide, originated at depth in an evaporitic formation, is used to explain the presence of massive gypsum deposits in the Mt. Cucco and the Faggeto Tondo caves.

The distribution and the morphology of more than 30 caves in the system, the presence of gypsum, always located along faults, and the presence of broken stalactites and columns, suggest that the evolution of the karst system has been controlled by tectonic movements.

Relationships between the development of the caves and the geomorphic evolution of the area are proposed.
\end{abstract}

\section{INTRODUCTION}

The purpose of this report is to relate knowledge about the location, shape, internal deposits and relative age of different levels of caves to the geomorphic and tectonic history of the area in order to understand the origin and evolution of the Mt. Cucco karst complex. Since the karst complex, as it appears today, is the result of a long sequence of tectonic, geomorphic and hydrologic events, understanding its origin and development is important in understanding the geomorphic evolution of a whole section of the Apennines.

The karst complex is located in the northern sector of the UmbriaMarches fold belt, in central Italy. It is developed on the western limb of one of the major anticlines that, in an en échelon pattern, form the anticlinorium known as the "Ruga Interna"' (SCARSELLA, 1951).

The complex is developed almost entirely in the Calcare Massiccio Formation (Upper Lias), a platform limestone that is the lowest outcrop- 
ping formation of the Umbria-Marches stratigraphic sequence (see Fig. 1 and Fig. 2 I, II). As pointed out by PASSERI (1972) caves are formed in the Calcare Massiccio limestone because of its high original porosity and permeability. Caves rarely develop in the overlying limestones, marls and shales because these rocks have a low, or very low, permeability, and a low secondary porosity of tectonic origin (PASSERI, 1972).

\section{THE KARST COMPLEX}

The Mt. Cucco karst complex, is developed almost entirely underground despite the presence of the deep Rio Freddo canyon, few superficial caves, few sinkholes and karrens. More than thirty caves are present, ranging in length from a few meters to several kilometers. Two in particular are important in understanding the geomorphic and hydrologic history of the area and will be discussed in this paper: the Mt. Cucco cave and the Faggeto Tondo cave.

The Mt. Cucco cave, more than 25 kilometers long and 922 meters deep, represents one of the most impressive cave complex in Italy. The cave, as shown in a Southwest-Northeast vertical cross section of the area (see Fig. 2 III), consists of several sets, or levels, of galleries connected by deep pits. The galleries dip gently westward along the western limb of the anticline. They have been formed along zones of higher synsedimentary porosity, developed between oolites, oncolites and birdseyes. The galleries in each level are mostly sub-parallel, few are anastomized, with a rounded, cylindrical shape suggesting a phreatic origin. Only a few of the existing galleries are now accessible by cavers; most of them are plugged with mud or flowstones. Their existence can be inferred from the morphology and the distribution of the other known galleries in the cave.

The absence of any sign of gully erosion on the gallery's floors shows that the phreatic levels have not been affected by any important vadose erosive process. This fact, as will be shown later, is important in understanding the evolution of the entire karst complex.

The different levels of the cave are connected by pits developed mainly along major tectonic discontinuities such as faults and joint systems. These pits are never older than the sub-horizontal levels that they intersect. Good examples of pits intersecting older sub-horizontal levels are: the Saracco pit, which is developed along a fault or a set of joints and intersects the galleries coming from the Staffa region and going to the Barba- 


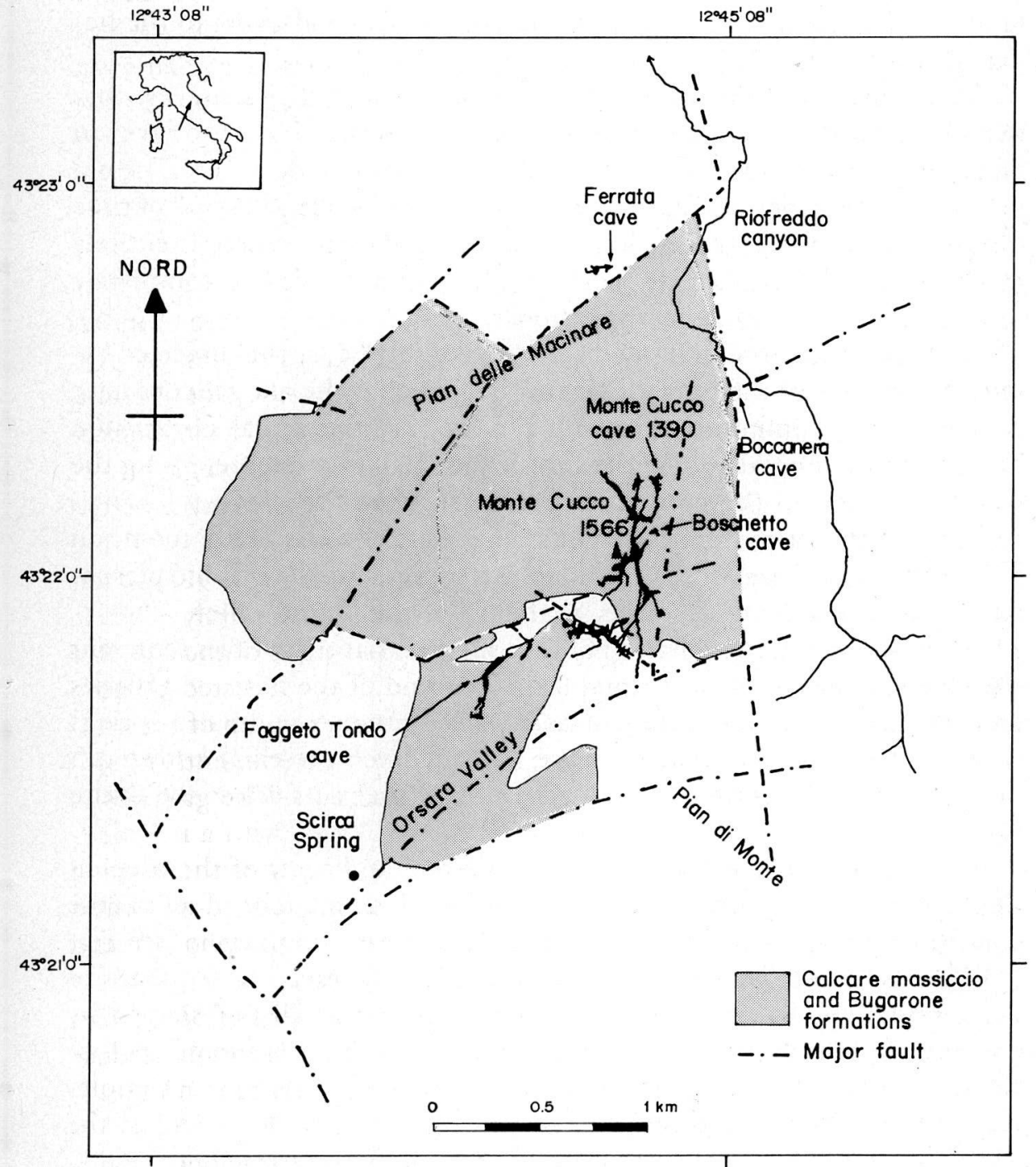

Fig. 1 - The Mt. Cucco karst area. The gray pattern represents the area where the Calcare Massiccio and the Bugarone formations (Condensed Sequence) outcrop. 
ri area; the Gitzmo and Px pits that intersect three different levels; and the Bicco, Berro and Torino pits that, having formed along an East-dipping fault, cut the galleries coming from the Orco gallery and going to the Italian area (see Fig. 2 III).

The shape and the spatial distribution of the galleries suggest that two different drainage systems have been active in the Mt. Cucco cave; an older, entirely phreatic system and a younger, mostly vadose one. The old phreatic system is very complex. It has been active for a long period of time forming different levels of galleries and pits. Today the system is entirely obsolete; the galleries are dry and, locally, partially filled or completely plugged by mud, boulders or flowstones.

The presence of several small caves on the surface, at the projected extensions of most of the phreatic levels, suggests that the old galleries have been in direct communication with the surface, the actual obstruction being only a temporal and later event. Some small caves, representing the paleo-entrances* of the system, are present on the surface only a few meters or tens of meters from the Terminale gallery and the Staffa room, on the eastern side of the Mt. Cucco ridge. Also several small caves are present on the western side of the ridge, at the tip of the Orsara valley.

The shape and the relative position suggest that these caves represent the paleo-springs of the cave complex. The trend of the phreatic galleries and the presence on the surface of both paleo-entrances and paleo-springs suggests that some, or even all, of the phreatic levels presently known can be considered as a former hydrological tunnel that cuts across the entire ridge.

The new drainage system is much different and completely independent from the old phreatic one. It is developed completely under vadose conditions along tectonic discontinuities. The Meandrino gallery (see Fig. 2 III), the longest known section of the vadose system, is a sequence of characteristically narrow, meandering galleries and small pits shaped by the retrogressive erosion of waterfalls. Its overall shape is vaguely hyperbolic, suggestive of the equilibrium profile of an external river; it is completely different from the almost linear, structurally controlled trend of the old phreatic levels.

The Faggeto Tondo cave, 1.5 kilometers long and 350 meters deep, is far less complex than the Mt. Cucco one. The cave developed during at

* The term paleo-entrances is used to mean paleo-entrances to the phreatic system. 


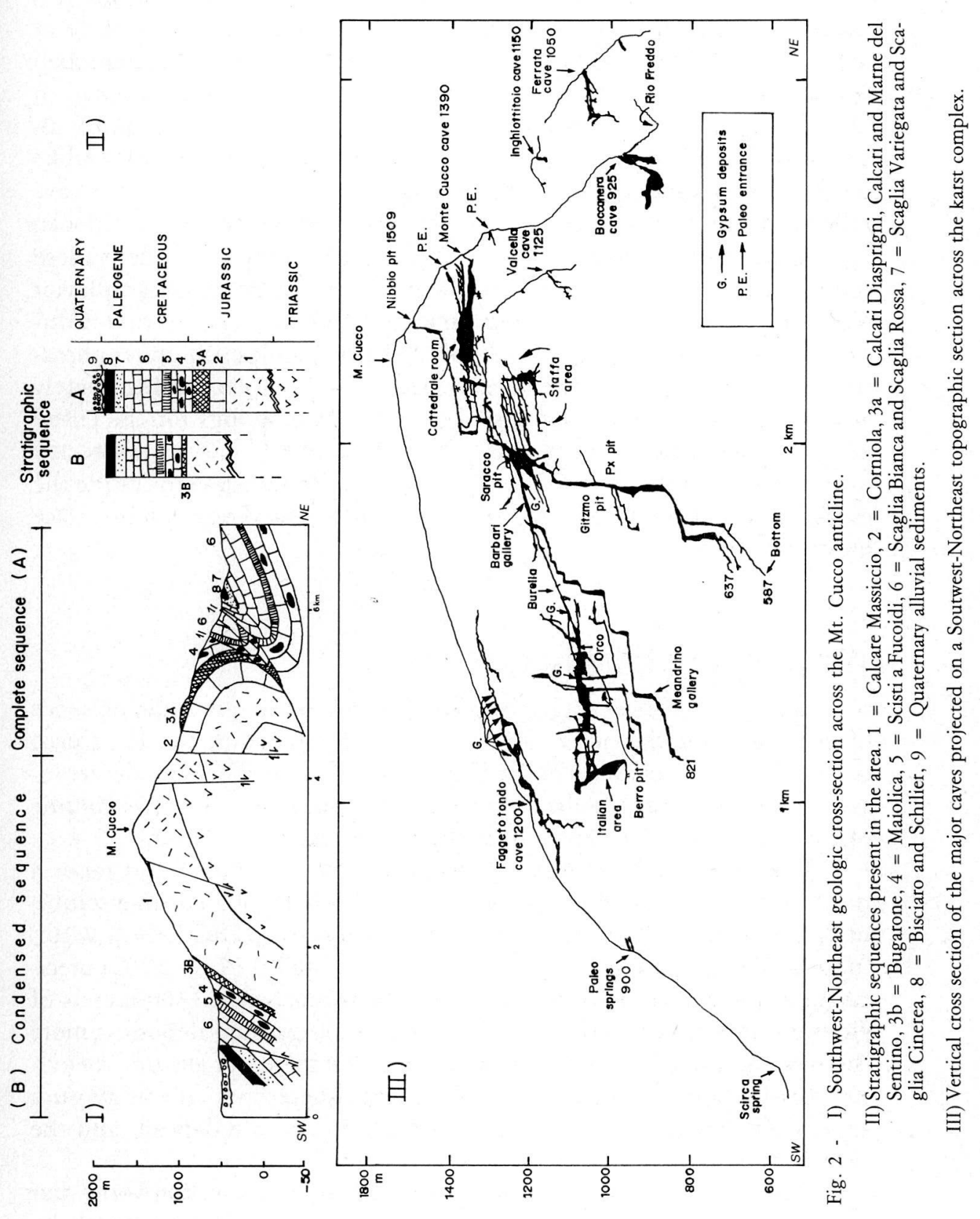


least two different periods. The upper level of the cave, in the upper section of the Calcare Massiccio Formation, represents the first stage of development, in a phreatic environment. This part of the cave is no more than 20 or 30 meters below the topographic surface. A later event resulted in the formation of deep sub-vertical pits along tectonic discontinuities, always in a phreatic environment as suggested by their morphology. Unlike the Mt. Cucco cave, the new drainage system in the Faggeto Tondo cave follows the old galleries, eroding gullies and small ravines on their floors.

At the present time almost all of the karst complex is under vadose conditions. All the internal streams show a characteristic seasonal behavior with very low runoff during the summer and high or very high runoff during the rainy season. The only part of the karst complex still under phreatic conditions is probably the deepest part of the complex, approximately at the level of the Scirca springs, the only known springs for the entire karst complex (BerTOluCCI ET AL., 1975; BOILA ET AL., 1983; DragONI ET AL., 1982). Only a few and local perched aquifers are present inside the caves in form of small lakes and siphons. This is typical of the sub-surface karst hydrology.

\section{THE ORIGIN OF GYPSUM DEPOSITS}

A peculiar characteristic of the Mt. Cucco karst system is the presence of gypsum inside the caves. Gypsum is presnt both inside the Mt. Cucco cave and in the upper level of the Faggeto Tondo cave. The deposits are located everywhere near faults or joints, along two levels. The total volume of the gypsum can be estimated as slightly in excess of $1 \cdot 10^{3} \mathrm{~m}^{3}$.

The presence of abundant gypsum deposits is peculiar and raises a number of questions. How can gypsum, a calcium sulphate with a solubility product higher than that of calcium carbonate $\left(\mathrm{K}_{\mathrm{sp}} \mathrm{CaCO}_{3}=4.2 \cdot 10^{-7}\right.$ $\mathrm{mol} / 1, \mathrm{~T}=20^{\circ} \mathrm{C} ; \mathrm{K}_{\mathrm{sp}} \mathrm{CaSO}_{4} \cdot 2 \mathrm{H}_{2} \mathrm{O}=2.3 \cdot 10^{-4} \mathrm{~mol} / 1, \mathrm{~T}=25^{\circ} \mathrm{C}$ ) precipitate inside a cave? How can it be present at more than 1300 meters of elevation inside a cave when the nearest external gypsum deposit is more than $10 \mathrm{~km}$ to the East and at no more than 450 meters of altitude (SERVIzio Geologico D'ITALIA, 1979)? Moreover, where does all this gypsum come from? Does any connection exist between gypsum deposits and the cave development?

The Mt. Cucco karst complex is not the only one in the world that contains gypsum. In the United States, several caves contain gypsum de- 
posits: the Carlsbad caverns in the Guadaloupe Mountains of southeastern New Mexico, the Crevice cave in Iowa and the Kane cave in Wyoming are some of them.

A number of hypotheses have been proposed to explain the origin of the massive gypsum deposits inside these caves. In particular, two different groups of hypotheses are available in the literature. A traditional group considers gypsum as a deposit from sulfate-laden waters during a secondary event in the cave history (J.H. BRETZ, 1949; L. HOBERG, 1949; GoOD, 1957). A second group considers gypsum as the result of the replacement of the calcium carbonate by sulfate, or the solution of calcium carbonate by a mechanism involving sulfate precipitation. The deposition of gypsum is thought to be contemporaneous to the cave development. At least three different mechanisms have been proposed:

MOREHOUSE (1968) and JAGONOW (1978) proposed a mechanism involving the oxidation of pyrite $\left(\mathrm{FeS}_{2}\right)$ and the production of sulfuric acid (HOwARD, 1960). The chemistry can be summarized as follows:

$4 \mathrm{FeS}_{2}+15 \mathrm{O}_{2}+14 \mathrm{H}_{2} \mathrm{O}+16 \mathrm{CaCO}_{3}[\rightarrow] 8 \mathrm{CaSO}_{4}+2 \mathrm{Fe}_{2} \mathrm{O}_{3}[\cdot] \mathrm{nH}_{2} \mathrm{O}+$ $8 \mathrm{Ca}^{++}+16 \mathrm{HCO}_{3}^{-}$

PALMER ET AL. (1977) suggested a large-scale gypsum replacement of carbonate in the deep phreatic zone, following the reaction:

$2 \mathrm{H}_{2} \mathrm{O}+\mathrm{CaCO}_{3}+\mathrm{SO}_{4}^{--} \longrightarrow \mathrm{CO}_{3}^{--}+\mathrm{CaSO}_{4} \cdot 2 \mathrm{H}_{2} \mathrm{O}$

Finally EGEMEIER (1973) proposed a 3-step gypsum replacement mechanism acting near the air-water interface and based on a sulphuric acid reaction produced by oxidation of hydrogen sulfide in the cave forming water. The chemical equilibria are as follows:

$$
\begin{aligned}
& 2 \mathrm{H}_{2} \mathrm{~S}+\mathrm{O}_{2} \longrightarrow 2 \mathrm{~S}+2 \mathrm{H}_{2} \mathrm{O} \\
& 2 \mathrm{~S}+2 \mathrm{H}_{2} \mathrm{O}+3 \mathrm{O}_{2} \longrightarrow 2 \mathrm{HSO}_{4}^{-}+2 \mathrm{H}^{+} \\
& \mathrm{HSO}_{4}^{-}+\mathrm{H}^{+}+\mathrm{H}_{2} \mathrm{O}+\mathrm{CaCO}_{3} \longrightarrow \mathrm{CaSO}_{4} \cdot 2 \mathrm{H}_{2} \mathrm{O}+\mathrm{CO}_{2}
\end{aligned}
$$


DAVIS (1980) suggested that hydrogen sulfide could originate at depth in oil-bearing evaporitic rocks where condition were anaerobic. The reaction, with or without the presence of sulfur-reducing bacteria (KIRKLAND \& EVANS, 1976; DAZY \& GRILLOT, 1982), is as follows:

$$
\mathrm{CaSO}_{4}+\mathrm{CH}_{4}(+ \text { Bacteria }) \longrightarrow \mathrm{H}_{2} \mathrm{~S}+\mathrm{H}_{2} \mathrm{O}+\mathrm{CaCO}_{3}+\text { Energy }
$$

DAVIS (1980) proposed that the hydrogen sulfide originated via the reaction (4) and then ascended in solution along faults to the cave level. On becoming aerated at the water-air interface, the hydrogen sulfide oxidized to sulphur and/or sulphuric acid which, on encountering limestone, reversed the replacement process and converted calcite to gypsum according to the Egemeier proposal (reactions (3)).

In the Mt. Cucco cave, three deposits of massive gypsum are known to date. They are located in the first part of the Barbary gallery, in the final section of the Burella gallery and in the Orco gallery (Fig. n. 2 III). In the Barbari and Orco galleries, gypsum seems to be laying on the cave floor whereas in the Burella gallery gypsum seems to be part of the cave floor.

The amount of gypsum is much greater in the Faggeto Tondo cave, despite its small size. Gypsum is spread along the upper part of the cave and, as in the Mt. Cucco cave, it is located near to or dewnslope from faults or major joints.

These sulphate deposits have not originated by precipitation from standing waters, either in a vadose or phreatic environment. They are scattered and too far away from any possible paleo-entrance of the system. If they originated from cooling waters coming from outside the caves, the deposition should have taken place in the part of the caves closest to the surface, not at depth. Moreover, the only known external source of gypsum is the Gessoso Solfifera Formation (Messinian) with the closest outcrops more than $10 \mathrm{~km}$ to the East and at only 450 meters of elevation (SERVIzIO GEOLOGICO D'ITALIA, 1979). It is difficult to think of a mechanism that could transport gypsum for such a long distance and across a major ridge.

Similarly, the gypsum is probably not derived from pyrite oxidation via the mechanism proposed by Morehouse and Jagonow. The UmbriaMarches sedimentary sequence does not contain pyrite or any other sulfide in sufficient quantities for the process to take place.

The presence of gypsum in the area can probably be explained by the Egemeier-Davis proposal. A 2000 meter thick sequence of anydrite and dolomite at depth under the Calcare Massiccio Formation could be the source for the hydrogen sulphide. This sequence, the Anidridi di Burano 
Formation, never outcrops, but it has been drilled for more than 1000 meters of thickness 20 kilometers Northwest of the studied area and it is commonly believed to underlie the Calcare Massiccio Formation in the Umbria-Marches area. A very small amount of hydrocarbon in the anydrite could generate hydrogen sulphide (KIRKLAND \& EVANS, 1976; DAZY \& GRILLOT, 1982) which could rise in water along normal faults to the level where it could be mixed with fresh water, causing in turn the oxidation of hydrogen sulphide, the production of sulphuric acid and the replacement of limestone by gypsum (EGEMEIER, 1973; DAVIS, 1980).

This replacement process, limited in space and time by the quantity of hydrogen sulfide available, could take place both inside already existing caves or outside the caves. Since the solubility of gypsum in water is high and the total volume of the deposits was probably small, only the deposits inside the caves could survive surface weathering and dissolution.

This model can explain why gypsum is always located near faults, the difference in volume among different deposits and their morphological appearance.

\section{TECTONIC AND GEOMORPHIC IMPLICATIONS}

The hydrologic conditions in the area have been changed several times during the formation of the caves. Each level of galleries in the Mt. Cucco cave can be considered as an old and independent hydrological level, suggesting that the karst complex has not been developed all at the same time but instead through several steps, at least one for each main level of galleries.

Most of the galleries have been formed under phreatic conditions; both the rounded shape and the linear trend support this idea. Moreover the gallery's floors do not show evidence of later gully erosion, suggesting that no important vadose event ever took place inside the caves. The transition from an old phreatic level to a deeper, new one has always been fast enough not to leave ravines or canyons.

Only a few galleries in the Mt. Cucco cave have formed under vadose conditions. These galleries represent the actual underground drainage system. They generally follow tectonic discontinuities and they are everywhere youngest than the old phreatic levels that they intersect.

In order to understand the genesis and development of the karst complex, two different models of evolution of the Mt. Cucco cave have been 
prepared by the author (Fig. 3). The first model (A) is based on the hypothesis that the discharge area drops while the recharge area remains at a relatively constant, higher level. The fall of the discharge area can be the result of the erosion of an impermeable layer (i.e. Bungarone or Scisti a Fucoidi Formations) as well as the down-dropping action of an active normal fault, or even a combination of both mechanisms. Which mechanism has been active is not important from a speleogenetic point of view; the erosive mechanism being probably only more gradual than the tectonic one.

The model shows that each time the discharge area drops, the active level of phreatic galleries is suddenly abandoned in favor of a deeper, new one. The model, however, cannot explain the presence of some galleries, such those in the Staffa area.

The Staffa area is characterized by phreatic and anastomized galleries, close to the surface at 1300 meters of elevation. The origin of these galleries and the presence of paleo-entrances at their projections to the surface can only be explained by assuming that the recharge area, as well as the discharge area, drops in elevation. This is the hypothesis used to prepare the second model (B) of figure 3 . The recharge and discharge areas probably did not always drop simultaneously or with the same amount of offset. The differential drop can explain why the phreatic levels are not perfectly parallel.

In the second model (B) (Fig. n. 3), the drop of both the recharge and discharge areas is thought to be due to the action of normal faults. The evidence that gypsum deposits are always located near tectonic discontinuities supports the idea of an important tectonic activity and suggests that the rise of sulphate-laden water along normal faults can be related to hydrothermal pumping, caused by an unusually intense tectonic activity in the area. In this view, each main level of sub-horizontal galleries represents a period of relative quiet in between periods of intense seismic and tectonic activity that down-dropped the recharge and/or the discharge areas, and eventually resulted in the deposition of gypsum.

The presence in the upper level of the Mt. Cucco cave (Cattedrale room and Galleria Terminale) of several broken stalagmites and columns suggests that the area has been affected by recent tectonic activity (this section of the Apennines is currently active). The dripstones do not seem to be broken for instability reasons (i.e. overweight). Columns up to 1.5 meters in diameter have been broken and shifted several centimeters along horizontal planes. Broken and non linear stalagmites have been observed in other caves of the Umbria-Marches area (FORTI ET AL., 1983; FORTI \& 


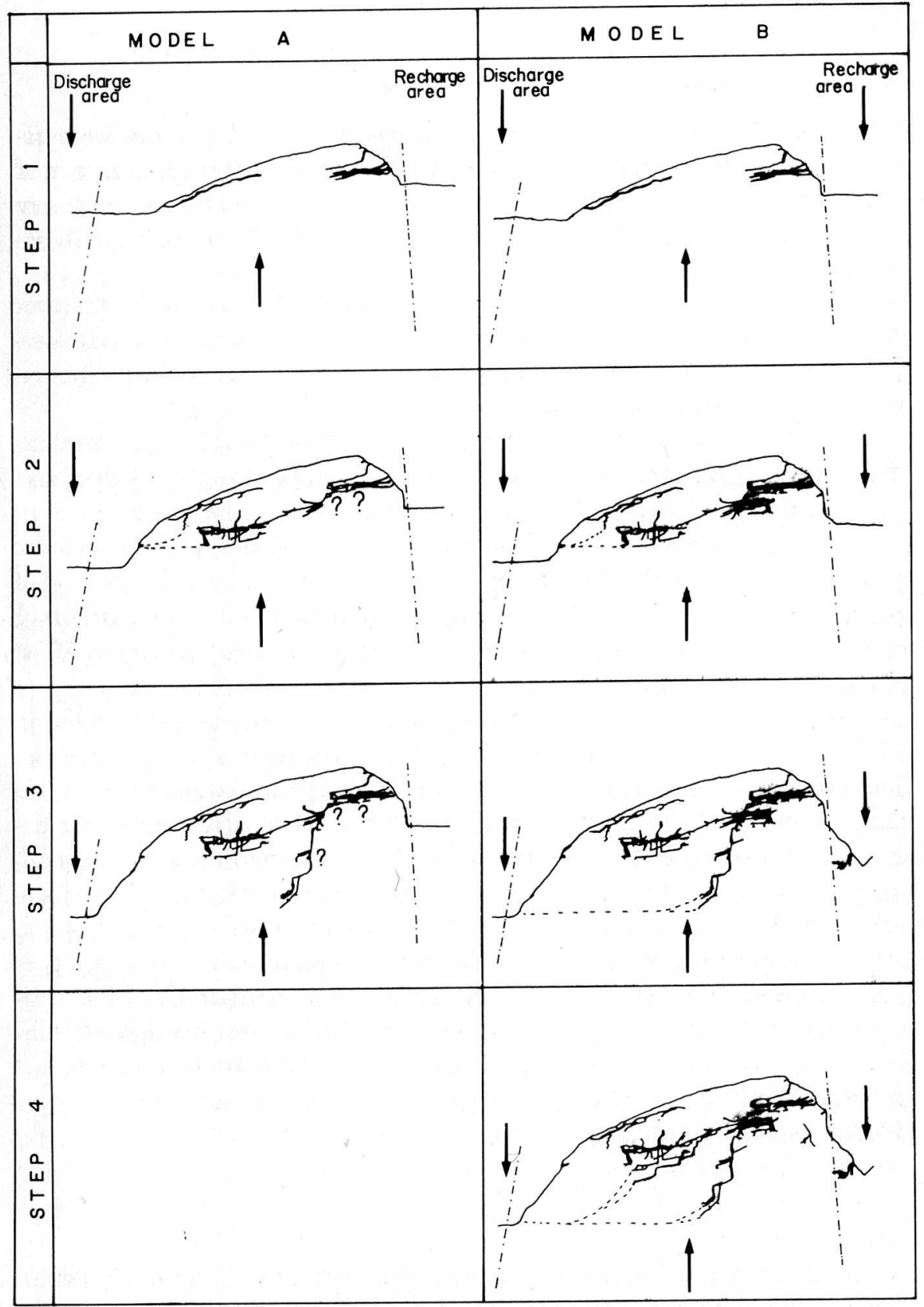

Fig. 3 - Two different models for the evolution of the Mt. Cucco karst system.

Model A is based on the hypothesis that the discharge area drops while the recharge atea remains at a relatively constant, higher level. The fall of the discharge area is the result of the down-dropping action of a normal fault. This model cannot explain the presence of the galleries in the Staffa area.

Model B is based on the assumption that both the recharge and discharge areas drop because of the down-dropping effect of normal faults. This model can explain the origin and evolution of all the known galleries in the cave system. The discharge and the recharge areas are only outlined. Their real position during each step may be different from what shown in the figure. 
POSTPISCHL, 1984). These authors proposed that the dripstones were tilted, and eventually broken by neo-tectonic movements. The presence of broken or non linear stalagmites and columns cannot be related to any particular tectonic event, but it suggests that the area has been recently active.

The history of the Mt. Cucco karst complex is related to the tectonic and geomorphic evolution of the entire area. The karst complex, as it is today, is the final product of a complex series of events that changed the hydrology of the area several times.

The active hydrologic condition, even if not completely clear, is relatively simple. The watershed strikes North following the highest ridges and only in a few places it is slightly shifted. Where a major river (i.e. the Sentino river) cuts across the entire anticlinorium, the divide is shifted to the west and water is diverted from the Tyrrhenian side to the Adriatic side of the watershed. Where an underground, structurally controlled, drainage system is acting, as in the Mt. Cucco area, water is diverted to the West and the divide is shifted to the East.

The present situation is probably, in many aspect, similar to those in the past during periods of relative tectonic quiescence. During those periods, a well-developed underground drainage system could slowly form along the west-dipping strata of the Calcare Massiccio, diverting an increasing amount of water from East to West. The intermediate periods of intense tectonic activity resulted in a rapid change of the quiescent situations, causing a relative uplift of the anticlinorium. In the karst complex, the current phreatic levels were suddenly abandoned in favor of new, deeper ones; while the Sentino river, because of the relative uplift of the anticlinorium, lost the upper part of its water basin. The result was a more linear watershed, with no, or few, deviations from the highest ridge line. At the end of each tectonicly active period, the entire system gradually adjusted to the new conditions.

\section{FINAL REMARKS}

More work needs to be done to fully understand the origin and evolution of the Mt. Cucco karst complex; nevertheless a few conclusion can be drawn:

- The karst complex has not formed all at one time, but instead it is the result of the tectonic, hydrologic and geomorphic evolution of the entire area. 
- The gypsum deposits present inside the caves are the result of the reaction of sulphuric acid, derived from the oxidation of hydrogen sulfide with limestone. The hydrogen sulfide originated at depth in the Anidridi di Burano Formation and rose to the caves level along normal faults.

- The tectonic behaviour of the Mt. Cucco area, as suggested by the karst complex development, can perhaps be related to a stick and slip movement along major local faults.

- If gypsum is dated at least one of the tectonic events that took place in the Umbria-Marches Apennines can also be dated.

The model proposed for the evolution of the studied karst complex does not take into accout any major change in the climatic conditions of the area. If the climate and, in particular, the amount of rain changed very much during the development of the cave, as it is probably the case, the evolution of the entire complex would be much more complex than that predicted by the model.

\section{AKNOWLEDGEMENTS}

The author wish to tank Earl E. Brabb and Dave Trum of the U.S. Geological Survey-Menlo Park, for the important suggestions on a first draft of this report and Walter Dragoni, University of Perugia, for reading a later draft of this report. The author wish to tank also all the people of the Gruppo Speleologico C.A.I. Perugia and the Centro Nazionale di Speleologia "Monte Cucco" for the invaluable job they have done to explore and map the Mt. Cucco karst system; without their efforts this paper would not have been possible.

\section{REFERENCES}

BertoluCCI M., G. ReICHENBACH AND F. SALVATORI, 1975: Relations between Monte Cucco underground hydrology and Scirca spring. An. Spéléol., v. 30, n 4, p. 733741.

BOILA P., G. MARCHETTI AND B. MATTIOLI, 1983: Lineamenti idrogeologici della Struttura del Monte Cucco (Umbria). Int. Symp. Carso in Alta Montagna, Imperia, p. 313323. 
BRETZ J.H., 1949: Carlsbad Caverns and other caves of the Guadaloupe Block, New Mexico. The Journal of Geology. Vol. $57 n^{\circ} 5$ 447-463.

Davis D.G., 1980: Cave development in the Guadaloupe Mountain. A critical review of recent hypotheses. NSS Bull. Vol. 42 42-48.

DAZY J. AND J.C. GRILLOT, 1982: Le thermominéralisme péri-alpin: exemple de la region savoyarde (France). Revue de Géologie Dynamique et the Géographie Pysique. Vol. 23 F. 4 319-328.

DRAGONI W., F. MANNOCCHI AND L. UBERTINI, 1982: Simulazione delle portate di una sorgente carsica con modelli stocastici. Appl. e Idrologia, v. 17, p. 383-392.

EGEMEIER S.J., 1973: Cavern development by thermal water with a possible bearing on ore deposition. Stanford Univ. Thesis $88 \mathrm{p}$.

ForTI P., V. PETRINI AND D. POSTPISCHL, 1983: Ricostruzione dei fenomeni paleosismici da strutture carsiche. Rend. Soc. Geol. It., $\mathrm{n}^{\circ} 14$.

FORTI P. AND D. POSTPISCHL, 1984: Seismotectonic and paleoseismic analysis using karst structures. Marine Geol. v. 55.

Good J.M., 1957: Non Carbonate deposits of Carlsbad Caverns. N.S.S. Bull., $\mathrm{n}^{\circ}$ 19, $\mathrm{p}$. 11-23.

HARDIE L.A., 1967: The gypsum - anidrite equilibrium at one atmosphere pressure. Amer. Min. Vol. 52 171-200.

Hoberg L., 1949: Geomorphic history of the Carlsbad Caverns area, New Mexico. The Journal of Geology. Vol. $57 \mathrm{n}^{\circ} 5$ 464-476.

How ARD A.D., 1960: Geology and origin of the Crevice caves of the Iowa, Illinois, and Winsconsin lead-zine district. Jour, Yale Speleo. Soc., 2, 61-95.

JAGONOW D.H., 1978: Geology and speleogenesis of the Ogle cave. N.S.S. Bull. Vol. 40 7-18.

KIRKLAND D.W. AND R. EvaNs, 1976: Origin of limestone butters, Gypsum Plain, Curberson County, Texas. A.A.P.G. Bull. v. 60, $\mathrm{n}^{\circ} 11$, p. 2005-2018.

MOREHOUSE D.F., 1968: Cave development via the supfuric acid reaction. N.S.S. Bull. 30 $1-10$.

PALmer A.N., M.V. PALMer, J.M. QUEEN, 1977: Speleogenesis in the Guadaloupe mountains New Mexico: Gypsum replacement of Carbonate by brine mixing. Int. Speleological Congress Proc., Shiffield England 336-339.

PASSERI L., 1972: Ricerche sulla porosità delle rocce carbonatiche nella zona di M. Cucco (Appenino umbro-marchigiano) in relazione alla genesi della canalizzazione freatica). Le Grotte d'It., v. 3, p. 5-44.

SCARSElla F., 1951: Un aggruppamento di pieghe nell'Appennino umbro-marchigiano. La catena M. Catria, M. Cucco, M. Penna, Colfiorito, M. Serano. Boll. Com. Geol. d'It., v. 73.

Servizio Geologico D'Italia, 1979: Carta Geologica d'Italia (Scala 1:50.000), Foglio n ${ }^{\circ}$ 301 - Fabriano.

SMITH A.R., 1978: The caves of Mekittrich Hill: Geology. in: Kunath Ed. The caves of Mekittrich Hill, 56-68. 